\title{
ON THE RELATIONSHIPS OF THE RHETORICAL, MODAL, LOGICAL, AND SYNTACTIC PLANES IN ESTONIAN PROVERBS
}

\section{Part 2}

\section{Arvo Krikmann}

\section{SOME SYNTACTIC STEREOTYPES}

The clearest and most effective indicators of the stereotypicality of proverbs are not, however, the basic formulae of logic and degrees of modality or the basic patterns of semantic transformations or other similar constructs, but rather syntactic clichés with their more or less clear correlations with stereotypes occurring on other levels.

Similarly, the well-known formula-like, or ornamental character of proverbs which has led some scholars to believe that it is possible to subject proverbs to a logical description, manifests itself first and foremost as syntactic symmetry (in Estonian inevitably accompanied by morphological symmetry). In the proverbs of BalticFinnic peoples (Finns, Karelians, Estonians, Votes) whose fondness of the so-called 'runic verse' can be observed in a considerable part of their "metric" folklore in several genres, structural symmetry is particularly frequent and pure, especially as compared to German or Russian proverbs, for example, in which end rhyme with its anti-parallelist effect is much more frequent. Syntactic symmetry is, by nature, yet another aspect of parallelism. Having - in the above discussion of the logical structure of proverbs - pointed out a parallelist supra-implicational level, we should like to emphasize that in proverbs, manifestations of parallelism are certainly not confined to this supra-level, but reach the basic implicational level as well. 
A large number of syntactic stereotypes can be found in the proverbs of different nations. Some of them are associated with certain patterns called syntactic formulae such as,

Kes..., see... (He who..., ...);

Kui..., siis... (If / When..., (then)...);

Kuidas..., nõnda..., (Like..., like...);

Parem..., kui... (Better..., than...);

Igal... oma... (Every... has its own...) etc., marked, as we can see, even lexically. The rest are just frequently recurring syntactic patterns. Examples of such stereotypes can be found in the introduction to Vanasõnaraamat (Book of Proverbs) and in my articles on logical structure of proverbs (Krikmann 1984 and 1987). Until recently, there was no systematic account of the stereotypes and their productivity in Estonian proverbs. The survey below, however sketchy, is an attempt to fill this gap.

Ever since Eleanor Rosch' publications, cognitive psychology and linguistics have been interested in the so-called natural classifications and the related notion of a prototype. There is reason to believe that, instead of being formed on the classical basis of the generic and the specific, natural classifications rather tend to be based on certain prototypes around which the human mind will build classes with indistinct, fuzzy boundaries, and such natural classifications are based on certain natural associations of properties, or syndromes. The trouble with natural classifications is that they never cover everything that can be classified, and one way the natural classification (and language in general) can overcome this difficulty is to classify the world from a particular aspect and in just as much detail as necessary, doing it on the principle "something important and the rest". As a result, we have, say, wedding songs, swinging songs, Martinmas songs, cradle songs, harvest songs etc., and in addition, "just songs". Even some more consistent natural classifications may be structured radially on the principle "something important versus all the rest" and if such a classification comes from an alien culture, it may strike us as absurd and totally illogical, for we just do not know what is considered important in that culture and what is not.

Two beautiful examples of such classification have been quoted side by side by the cognitivist semanticist and metaphor theorist George Lakoff (1987:92ff). 
Example 1 represents fiction. This is J.L. Borges' classification of animals, taken as if from a fictitious Old-Chinese encyclopaedia Celestial Emporium of Benevolent Knowledge.

Example 2 represents reality, showing the classification of objects in the Dyirbal language, which is one of the aboriginal languages spoken in Australia (Lakoff says he has borrowed the example from R.M.W. Dixon).

[See also, e.g., http://www.virtualschool.edu/mon/SocialConstruction/ LakoffWomenFireDanger.html]

The following attempt to classify formal stereotypes bears a close resemblance to the above examples, especially the "Old-Chinese" one. There is no fixed level hierarchy, instead I have just tried to guess what the prototypes might be. The classification is not even purely syntactic, being based on syntactic as well as on modal features. The attention has been concentrated on

(1) whether the proverb contains imperative components or not,

(2) whether there is a parallelist high level in the text structure or not, and

(3) whether the basic level of the text is expressed as a simple sentence or a symmetrical implication.

When analysing the material, I tried to simplify it as much as possible. As the units classified are individual texts (to be more exact, the head texts of authentic folk proverbs from the academic publication Eesti vanasõnad (Estonian Proverbs), 12671 texts in total), the effects of syntactical or modal synonymy cannot be observed. Every untypical and/or complex and/or hybrid form has been eliminated from discussion. Nothing at all has been said about simple sentences (to save space and effort).

So I came up with the following list of eight syntactic-modal metaclasses, or prototypes. The prototypes have been accompanied by rather inaccurate and preliminary assessment of their frequency in Estonian archive material: the T-column carries the number of different proverb types following the pattern in question, while the V-column shows how many authentic archive texts are represented by the types. (This number is just a rough approximation as every productive proverb is characterized by a syntactic variation not at all less rich than lexical variation.) 


\begin{tabular}{|l|l|r|r|}
\hline & \multicolumn{1}{|c|}{ Class } & $\mathrm{T}$ & \multicolumn{1}{|c|}{$\mathrm{V}$} \\
\hline A. & Indicative simple sentences & 2730 & 18450 \\
\hline B. & Non-equative sentences with recurrent parts & 490 & 1580 \\
\hline C. & Equalities and com parisons & 580 & 2630 \\
\hline D. & Inequalities (incl. preferences) & 710 & 4970 \\
\hline E. & Symmetric implicational patterns & 2660 & 15230 \\
\hline F. & Units with a parallelist supra-level (in total) & 2160 & 18100 \\
\hline G. & Units with an imperative verb form (in total) & 1450 & 9740 \\
\hline H. & Rhetorical questions & 390 & 2560 \\
\hline
\end{tabular}

Next, our modest attempt at classification will be presented in a more detailed way. For lack of space we have been able to provide the subclasses with but a few examples, no more than $10 \%$ of the total number of appropriate texts for smaller subclasses, and ab. $5 \%$ for bigger ones. Like the metaclasses, every subclass is provided with $\mathrm{T}$ and $\mathrm{V}$ values: if the name of the subclass is, for example, followed by the numbers (60-170), it means that our sample contains ab. 60 different proverbs of this type, representing about 170 authentic archive texts.

\section{A. Indicative simple sentences without co-ordinated parts or equalization}

In order to avoid remaining in total darkness, we shall present a very short list of the most widespread proverbs in the form of simple sentences, just ab. $1 \%$ of the appropriate proverb types.

Suur tükk ajab suu lõhki (A big piece will rend the mouth)

Käbi ei kuku kännust kaugele (A cone never falls far from the stump)

Häda ajab härja kaevu (Need drives an ox down the well)

Sõber sõbra perse koorib (A friend will skin another friend's arse)

Tühi toob tüli majasse (Want will bring strife to the house)

Valel on lühikesed jalad (A lie has short legs)

Veereval kivil ei kasva sammalt (A rolling stone gathers no moss)

Terav kirves leiab kivi (A sharp axe will find a stone)

Tühi kott ei seisa püsti (An empty sack cannot stand upright)

Oma kiitus haiseb (Self-praise stinks)

Ülekohus ei seisa kotis (Injustice won't keep in a sack)

Uus luud pühib puhta toa (A new broom sweeps clean) 
Käsi peseb kätt (A hand will wash another)

Hea sõna võidab võora väe (A kind word can win a hostile force) Ega agan agana pääle haugu (A grain-husk doesn't bark at another grain-husk)

Õige hõlma ei hakka ükski (No one will tear at a right man's coat)

Hunt hunti ei murra (A wolf will not kill another wolf)

Jagajale jäävad näpud (A dispenser will be left with his bare fingers)

Omad vitsad peksavad kõige valusamini (One's own rod beats the hardest)

Aeg annab head nõu (Time gives good advice)

Jakob viskab raudnaela heinasse (Jacob throws an iron nail into hay)

Ega nimi meest ei riku (A name won't spoil a man)

Uhkus ajab upakile (Pride will make a man topple over)

Igal linnul oma laul (Every bird has its own song)

Vagu lambaid mahub palju ühte lauta (Many meek sheep will find room in one shed)

Küll koer koera tunneb (A dog will recognize another)

\section{B. Non-equalizing sentences with recurrent parts}

B1. Sentences with contrasting predicative components (60170):

Naesterahval on pitkad juuksed, lühikesed mõtted (Womenfolk has long hair, but short minds)

Vaenelaps vaksa kasvab, kaks kahaneb (An orphan grows by a span, diminishes by two)

Jumala kivid jahvatavad pitkalt, aga väga peenikeste (Lord's millstones grind slow, but very fine)

Sügisel on suve silmad, aga talve hambad (Autumn has summer's eyes, but winter's teeth)

B2a. Affirmative sentences with synonymous predicative components (100-230):

Võõra leib kirg kikkani, vaak valgeni (A stranger's bread will crow till cockcrow, caw it will till the morning sun)

Nuur tüdrik, sel küpseb põrsas põvves, kana kaindlas ja nisuleib nisa all (A young maiden - well, such a one has a piglet growing 
on her bosom, a chick under her armpit and a wheaten loaf under the breast)

Edimine iki hiirtel, harakil (The first specimen will always go to mice and magpies)

Leisik liiva ja nael karvu sööb iga inimene aastas ära (Twenty pounds of sand and a pound of hair are in every man's yearly menu)

Talupojad toitvad saksad ja sandid (Peasants feed both gentlefolks and beggars)

Jaagobipäevast jääb kaste künka ääre, hall aja ääre (Since St. Jacob's Day dew will remain on the hill, hoarfrost will stay near the fence)

\section{B2b. Negative sentences with synonymous predicative components (30-70):}

Hüätego pala-ai tullõ, õi upu-ui vette (A good deed won't burn in fire, nor drown in water)

Ema ei sünni vakka ega varna (Mother doesn't fit in a bushel, nor on a peg)

Kitmine ei tii kedägi parembas, ei paksembas (Praise doesn't make anyone better, nor fatter)

B3. Sentences with recurrent parts, in which the predicative components stand in an ambiguous or vague relation (2030):

Külm ajab mehe ree pealt maha, istub ise peale (Frost drives a man off the sled and gets on himself)

Maailm läheb vanemaks ja pääv-päävalt ikka targemaks (The world gets older and, from day to day, wiser)

Raha tuleb, raha läheb (Money comes, money goes)

Inimene on ise oma jumal ja ise oma kurat (Man is his own God and his own Devil)

B4. Sentences with recurrent parts branching off on a calendary, or some other temporal principle (10-15):

Tedre lauluaeg peab olema kaks nädalad enne ja kaks pääle jüripäeva (A blackcock's singing time is two weeks before and two after St. George's Day) 
Enne ja pärast pärtlepäeva kolm päeva ollev lepp paju poolvelle (Three days before and after St. Bartholomew's Day alder is said to be willow's half-brother)

\section{Equalities and comparisons}

C1a. Equalities of the type $A$ is $B$ (20-100):

Tahtmine on taevariik (Desire is heaven)

Aeg on raha (Time is money)

Silm on kuningas (The eye is the king)

Leib on peremees (Bread is the master)

\section{C1b. Equalities of the type $A$ is $B$ 's $C$ and inverse forms of the type $B$ 's $C$ is $A$ (165-840):}

Habe on mehe au (Beard is a man's honour)

Suu on südame mõot (Mouth is heart's measure)

Naine on maja lukk (Woman is the lock of the house)

Laiskus on kuradi peapadi (Lazyness is the Devil's pillow)

Vaene on rikka roog (A poor man is a rich man's food)

Mees on naise pea (Husband is his wife's head)

Ettevaatus on tarkuse ema (Caution is the mother of wisdom)

Haigus on surma käsk (Disease is Death's messenger)

Lukk on looma vari (A lock is an animal's cover)

Tõnisepäev on talve hari (St. Anthony's Day is winter's ridge)

Tamm on talupoja raud (Oak is farmer's iron)

Lapsed on vaese varandus (Children are a poor man's fortune)

Musu on muu asja käsiraha (A kiss is a handsel for something else)

Koera palk on malk (A dog's reward is cudgel)

Teemehe lukk on sõlm (A wanderer's lock is a knot)

\section{C1c. Other be-predicated comparisons beginning with a subject (60-180):}

Mets on vaese mehe kasukas (Forest is a poor man's furcoat)

Kõht on kõige kurjem kubjas (Stomach is the most ruthless foreman)

Siga on ausa mehe leivakõrvane (Pork is an honest man's food beside bread)

Töö on lolli inimese ajaviide (Work is a fool's pastime)

Kannatus on kallis asi (Patience is a precious thing) 
Tarkus on tarviline vara (Wisdom is a valuable property)

Isa on pere leiva tugi (Father is the family's bread support)

C1d. Equalities of the form $A$ is half of $B$ and A is two Bs (15130):

Puhtus on puul elu (Cleanliness is half the life)

Kang om kats miist (A lever is two men)

C2. Equalities beginning with a declinable attribute (50-450):

Vaga siga koti naaber (A tame pig is a bag's neighbour)

Julge pealehakkamine on pool võitu (A brave beginning is half the victory)

Tühi kõht on kõige parem kokk (Hunger is the best cook)

Kuues külinädal on rohunädal (The sixth sowing week is a grass week)

Hea südametunnistus on pehme peapadi (A good conscience is a soft pillow)

Loll pea on kere nuhtlus (A stupid head is the body's scourge)

C3. Equalities beginning with a genitive attribute or an attributive word (30-80):

Loodetuul on taevaluud (North-Western wind is the sky's broom) Rahaahnus on kõige kurja juur (Greed for money is the root of all evil)

Heateo palk on kuri malk (The reward for a good deed is a bad cudgel)

C4a. Elliptic equalities with recurrent parts, or equalities with is or and as copula (40-120):

Teine inimene on teise kurat (A man is another man's Devil)

Vana tee - vana sõber (An old way [is (like)] an old friend)

Lapse nahk ja koera nahk (A child's skin and a dog's hide [should hardly be spared])

$\ddot{U} k s$ koer teise vader (A dog is another's sponsor)

C4b. Equalities with a full ellipsis or an and-copula, but without recurrent stems (10-70):

Kevadine päev - sügisene nädal (A spring day [is the same as] an autumn week)

Poisslaps - täkutsälg (A boy [is like ] a colt) 
Vihma vili ja põua sõkal (Rain's grain and a drought's chaff [are the same])

C4c. Verbless equalities with an or-copula (10-60):

Naise varast rikkust või koerasitast sõnikut ( [One never gets] any riches out of a wife's property or manure out of dogshit)

Salajutt või salasitt (Secret talk or secret fart [both will stink sooner or later])

Poesi kiil vai uisa kiil (A boy's tongue or a snake's tongue [are equally evil])

C4d. Equalities of the type $A$ and $B$ are the same $\sim$ alike (40130):

Lapse külm ja koera nälg on üks (A child's [feeling] cold or a dog's hunger are the same)

Naise rikkus ja titi pikkus on üks (Awoman's wealth and a prick's length are the same)

Lesk mees ja lõigatud koer on üks (A widower and a gelded dog are the same)

C5a. Comparisons beginning with a simple subject, and using the verb be (15-15):

Siga on nagu saks (A pig is like a gentleman)

Vanatüdrik kui kuijono kattai (A spinster [is] like a doddered juniper)

Elu on lühike nigu uni (Life is short like a dream)

C5b. Comparisons using the verb be or an ellipsis, beginning with a declinable attribute (15-70):

Kevadine lumi on kui kord sõnnikut põllule (Spring snow is like a layer of manure to a field)

Rikas naine kui resu silmas (A rich woman [is] like a dust in the eye)

Lesk mees nagu soendud supp (A widower [is] like warmed soup)

C5c. Comparisons using ellipsis or the verb be and beginning with a genitive attribute (30-70):

Mihe sugulane um ku tõprarasvaga ruug (Husband's kin is like a meal with suet [i.e. not as tasty as made with lard]) 
Laisa töö - nagu kana haudub mädamuna peal (A lazy man's work - like a hen sitting on a rotten egg)

Vaese elu on kui tuli toores puus (A poor man's life is [burning low] like fire in undried wood)

C5d. Comparisons with the verb be, the halves of which repeat certain declinable verb forms or their ellipses (1040):

Kolm korda kolida on niisamma hää ku üks kord põleda (To move thrice is as good as to burn down once)

Naestega vaidlemine on kui vasikaga võidu jooksmine (Arguing with women is like racing a calf)

Tütar mehele laulatetud on nagu kikk leivast ära leigatud (A daughter married to a man is like a slice cut off the loaf)

C5e. Comparisons with verbs other than be (15-70):

Uma kitt hais ku sitt (Self-praise stinks like shit)

Inimse elu ripub kui juuksekarva otsas (Human life as if hangs on a hair)

C6a. $A$ is $B$-equalities with the common feature made explicit (3-4):

Lapsed on linnud: saavad suled selga, ongi läinud (Children are birds: as soon as they get their feathers on they are gone) Poissmiis puulhärgä: säält sü̈̈, kost saa (A bachelor [is] half a bull: eats wherever he finds food)

C6b. A (is) like B -comparisons with the common feature made explicit (20-30):

Lesk naine kui madal aed, kust kõik üle lähvad (A widow [is] like a low fence where everyone goes over)

Talupoeg on nagu tolmune kott, ikka natuke tuleb (A peasant is like a dusty sack, a little can always be got out of it)

Tühi jutt on kui hundi sitt: must ja karvane (A gossip [literally: empty story] is like a wolf's shit: black and hairy) 
C6c. Comparisons beginning with $A$ and $B$ (are the same) or $A$ or $B$, with the common feature made explicit (10-15):

Siga ja sepp on üks: siga teeb sita, sepp teeb raua uueks (A pig and a blacksmith are the same: a pig makes shit new, a blacksmith makes iron new)

Sanna palamine vai latse kuulmine - väikene asi (A sauna burnt down or a child's death - both are trifles)

C6d1. $A$ and $B$-initiated equalities with the common feature made explicit, which are syntactically affirmative sentences with two subjects (130-590):

Rikka haigus ja vaese õlu on kuulsad (A rich man's illness and a poor man's ale are famous)

Noored neiud ja nisuleib lähevad ruttu vanaks (Young maidens and wheaten bread get old soon)

Naisterahva töö ja märahobuse söömine ei lõpe iial otsa (A woman's work and a mare's eating never end)

Puhas suu, puhas käsi käib maailma läbi (A clean mouth, a clean hand will travel round the world)

Mehine pere ja härine kari võtavad Jumala käest vägisi (A masculine household and a cattle of many oxen will take from God by force)

Vaeste vasikad ja rikaste lapsed surevad noorelt (Poor people's calves and rich people's children die young)

Surnu pära ja naise vara ei kesta kaua (A dead man's heritage and a woman's dowry don't last long)

C6d2. Neither A nor $B$-initiated equalities with the common feature made explicit, which are syntactically negative sentences with two subjects or two objects (40-200):

Laastutuli ja laenuleib ei kesta kaua (Neither chip fire nor borrowed bread last long)

Naisterahva viha ja vesikaare tuul ei anna enne järele kui vesi väljas (Neither a woman's anger nor the west-northwest wind give way before water comes)

Inimese tahtmine ega põrgu ei saa iial täis (Neither a man's desire nor hell ever gets fulfilled) 
C6e. Lists of more than two objects treated as similar, with the common feature made explicit (50-290):

Kana laulmise, naise vilistamise ja lehma möirgamise hääl kostab põrgu (The sound of a hen crowing, a woman whistling and a cow roaring will reach hell)

Ilmas pole kolme asja: kivil juurt, linnul piima, veel oksa (Three things are absent from this world: a stone's root, a bird's milk and water's twig)

Jürisid, Marisid, kõrvhobusid ja kõveraid puid kõik kohad täis (There are crowds of Jüris, Maris, sorrel horses and bent trees everywhere)

Üks täitsamees ei anna teisele tarvitada oma nuga, hobust ja naist (A real man won't make his knife, horse, or wife available to another man)

\section{Inequalities (including preferences) \\ D1a. Symmetric Better... than... -preferences (340-2930):}

Parem suutäis soolast kui maotäis magedat (Better a mouthful of salted food than a stomach full of sweet stuff)

Parem karta kui kahetseda (Better be cautious than repent)

Parem hoida kui oiata (Better beware than groan)

Parem vana habeme all kui noore piitsa all (Better under an old man's beard than under a young man's whip)

Parem korts kannas kui vill varbas (Better a wrinkle at the heel than a blister on the toe)

Parem on oma ema vits kui võeraema võileib (Better one's own mother's rod than a stepmother's buttered bread)

Parem oma riide soe kui teise mehe töö soe (Better one's own clothes' warmth than the warmth of working for another man) Parem kodu koorukesed kui võileib võorrsil (Better pieces of crust at home than buttered bread away from home)

Parem paluke leiba kui paha sõna (Better a piece of bread than a bad word)

Parem varblane peos kui tuvi katusel (Better a sparrow in the hand than a pigeon on the roof)

Parem söönu sööta kui koolu kosutada (It's better to feed a fed one than to restore a dead one)

Parem vana varjun kui noore ilun (It's better [to live] under an old man's shade than in a young man's beauty) 
Parem paksu painutada kui peenikest peran vedada (It's better to bend a plump one than to drag a slim one behind)

Parem oma ema must puder kui võóraema võileib (Better the dark porridge of your own mother than a stepmother's buttered bread)

Parem hüva rooga üle jätta kui vatsa revestada (It's better to leave some good food untaken than to split the stomach)

Paremb laih laudan ku väkev väl'ä pääl (Better a skinny one in the shed than a well-fed one in the field)

\section{D1b. Better-preferences with a nonsymmetrical simple sen-} tence structure (40-120):

Üks vana sõber on parem kui kaks uut (An old friend is better than two new ones)

Oma ema leib on parem kui võóraema võidleib (One's own mother's bread is better than a stepmother's bread and butter)

Õdagune uhetu om paremp ku hummugune mõstu (Rinsed in the evening is better than washed in the morning)

Kodu om paremb ku pidu (Home is better than a feast)

D2a. Sooner-inequalities with a symmetric structure (50330):

Enne saab külla küljest kui nälja otsast (You may sooner get something from plenty than from hunger)

Enne saab madal marja maast ku kõrge tähe taevast (A low one sooner gets a berry from the ground than a tall one picks a star from the sky)

Ennemb saat kidsi rikka käest kui helde vaese käest (You sooner get something out of a rich and stingy man than a poor and kind one)

D2b. Sooner-inequalities with the structure of a nonsymmetric simple sentence (15-110):

Veike kivi lükkab ennem koorma ümber kui suur (A little stone will upset a load sooner than a big one)

Emä põlve naal kasuse lats innembi ku esä salve naal (Leaning on its mother's knee a child will grow sooner than leaning on its father's bin) 
D3. More-inequalities (enam in Estonian) with a symmetric structure (20-220):

Enam saab ikka piskust tööst kui suurest seisust (More is achieved by a little work than by a long rest)

Enam tehakse nõuga kui jõuga (More is done by wit than by force)

Enamb saap suur suikja kui kavva magaja (A frequent dozer [i.e. a slow worker] gets more than a long sleeper)

D4. More-inequalities (enam or rohkem in Estonian) with the structure of a non-symmetric simple sentence (120-470): Arm aitab enam kui hirm (Love helps more than fear)

Laps on enam kui laast (A child is more [useful] than a splinter) Isa sõna enam kui ema vits (Father's word is more than mother's birch)

Tasane tsiga tsung enamb maad ku röhütelleja (A quiet pig grouts more than a grunter)

Väsinu hobesele om tema kõrva suurune kikk leibä enämb kui karnits kaaru (For a tired horse a slice of bread the size of its ear is more than a measure [3.28 l] of oats)

Naine jõuab põllega rohkem välja kanda kui mees koormaga sisse vedada (A woman can carry out more in her apron than a man can carry in by a load)

Jänes teeb ühe ööga rohkem jälgi kui varsaga hobune üle suve (A hare leaves more traces during a night than a mare with a foal during a summer)

D5. Symmetrically or non-symmetrically structured easierinequalities (10-30):

Kergem teist laita kui ise paremini teha (It's easier to criticize another person than to act better oneself)

Kergemb kul'ata ku tü̈̈d tetä (It's easier to rollick than to work) Rumalaste küsida on kergem kui targaste kosta (It's easier to ask a foolish question than to give a clever answer)

Hoobelda on kergem kui maksta (It's easier to boast than to pay)

D6. Bigger-inequalities with the structure of a non-symmetric simple sentence (15-20):

Sõna vägi on suuremb kui sõjavägi (The power of a word is bigger than [the power of] an army) 
Hunt üle aja minnes on suurem kui hobune (A wolf, when jumping over a fence, is bigger than a horse)

D7. Worse-inequalities with the structure of a non-symmetric simple sentence (10-15):

Liinah om hullõp ku laanõh (It's worse in a town than in a forest)

Proosta' olõk om hullõb ku'vargus (Vulgar manners are worse than stealing)

D8. Sweeter-inequalities with the structure of a non-symmetric simple sentence (5-30):

Kevadine muld on magusam kui sügisene ädal (Spring earth is sweeter than autumn aftergrass)

Uni on magusam kui mesi (Sleep is sweeter than honey)

D9. More precious-inequalities (kallim in Estonian) with the structure of a non-symmetric simple sentence (5-20):

Aus nimi on kallim kui kuld (An honest name is more precious than gold)

Raholine südä om kallimp kui kuld (A heart at peace is more precious than gold)

D10. Older-inequalities with the structure of a non-symmetric simple sentence (10-50):

Kaup on vanem kui meie (A deal is older than we are)

Käsk on vanem kui inimene (Fiat is older than man)

Õigus on vanem kui kohus (Justice is older than court [or: Right is older than duty])

D11. Wiser-inequalities with the structure of a non-symmetric simple sentence (10-160):

Muna on targem kui kana (An egg is wiser than a hen) Hommik on targem kui ôhtu (Morning is wiser than evening) Õhtu on targem kui hommik (Evening is wiser than morning)

D12. Inequalities with other comparative words (50-300):

Ondsam on anda kui võtta (It's more beatific to give than to take)

Veri on paksem kui vesi (Blood is thicker than water) 
Igavam on lehm lüpses kui tappes (A cow milked lasts longer than a cow killed)

Oma suu on ikki lähemal ku latse suu (One's own mouth is always closer than a child's mouth)

Kaks silma ulatavad kaugemale kui üks (Two eyes reach farther than one)

\section{D13. Various negative inequalities (20-150):}

Hunt ei ole nii suur, kui hurjutatakse (The wolf is not as big as it's rated)

Ega putru nii palavalt sü̈̈a, kui keedetakse (Porridge is never eaten as hot as it's cooked)

Muna pole targem kui kana (An egg is not wiser than a hen) Kurat pole kunagi nii hirmus, kui teda maalitakse (The Devil is never as terrible as it's painted)

\section{D14. Inequalities explained (5-10):}

Armastus on hullem kui soetobi: soetobi ajab pä̈̈ paljaks, armastus ajab pe-paljaks (Love is worse than typhoid fever typhoid fever pulls the head bald, love pulls the arse bald)

\section{E. Implications without a parallelist supra-level}

E1a. Elliptic texts interpretable as universal implications (400-2080):

Vaga vesi, sügav põhi (Still water, deep bottom [= Still waters run deep])

Üheksa ametit, kümnes nälg (Nine trades, hunger the tenth)

Persealune soe, ninaalune külm (Seat warm, food cold)

Unustab hoidja, tabab pü̈̈dja (Failed by the guardian, caught by the pursuer)

Varsan õpid, vanan pead (Learnt when a foal, kept when old) Harva käid, ausast peetakse (Seldom visiting, well treated) Rummal pä̈̈, pal'lu vaiva (A stupid head, lots of trouble) Kaste enne jüripäeva, rukis enne jaakobeid (Dew before St. George's Day, rye before St. Jacob's)

Hooletus ees, onnetus taga (Neglect first, accident next)

Kutsumata võerad, teadmata roog (Guests unbidden, food unknown)

Äkki haarad, suu palutad (Hastily grabbed, mouth burnt)

Otav kala, laih liim (Cheap fish, weak soup) 
Tasa sõidad, kaugemale jõuad (If you drive softly, you'll get farther [=Soft and fair goes far])

Paha koer, parem õnn (A bad dog, better luck)

E1b. Elliptic texts interpretable as universal implications or parallelist non-generalized patterns of the type $A$ and $B, A$, but $B$ etc. (20-920):

Palju lapsi, laiad silmad (Many children, wide eyes [Warning against eavesdroppers])

Öö ees, surm selja taga (Night ahead, death close behind)

Palju kisa, vähe villu (Big raw, little wool)

\section{E2a. Implications with If... then... (510-1080):}

Kui tõnisepäeval nii paljugi päikest paistab, et mees näeb hobuse selga hüpata, siis tuleb kena aeg (If there is enough sunshine for a man to get on horseback on St. Anthony's Day, there'll be nice weather)

Kui saad üle koera, saad ka üle saba (If you've got over the dog, you'll get over the tail as well)

Kui seitsmevennapäeval sajab, siis sajab seitse nädalat (If it rains on the Day of the Seven Sleepers [June 27], it will rain for seven weeks)

Kui küünlapääva ajal saab härg räästa alt juua, siis maarjapääva ajal ei saa kukkki (If a bull can drink from eavesdroppings at Candlemas, even a cock can't do it on Lady Day)

Kui paastumaarjapäeva öösel külmab, külmab veel 40 ööd (If it freezes on Lady Day night, it will freeze on 40 more nights)

Kui maarjapäeva ööl külm kanamuna väljas lõhki lööb, siis tuleb külm kevade (If an egg will crack outdoors of cold on Lady Day night, there will be a cold spring)

Kui kevade külm võtab konnakudu, võtab sügise vilja (If frog's spawn is frozen in spring cold, crops will be taken by autumn frosts)

Kui maarjapäeval lumi katusel, siis jüripäev hanged aia ääres (If snow lies on rooftops on Lady Day, there will be snowdrifts at fences on St. George's Day)

Kui mihklipäevaks puulehed maas, siis jüripäevaks rohi maas (If the trees are leafless on Michaelmas, it will be grassy on St. George's Day) 
Kui pü̈̈ad kõigest väest, saad üle igast mäest (If you try from all your might, you will get over every mountain)

On kange sõnn, siis ka kanged kohitsejad (If the bull is strong, the gelders are strong too)

Kui ei ole surmatõbi, siis saab ikka viinast abi (If the disease is not fatal, spirits will help)

Kui Jumal loob lolli, siis loob lollile ka molli (If God creates a fool, he creates a trough for him, too)

Kui mardipäeval Sõel selgelt looja läheb, siis tuleb hää viljaaasta (If the Pleiades set cloudless on Martinmas, there will be good crops next year)

Kui madisepäeväl saeab, siis on paelu marju ja mardikid (If it snows on St. Matthew's Day [February 24], there will be lots of berries and bugs)

Kui mardipäeval lumi katuste pääl, siis lihadepühade aeg kah (If snow is on roofs on Martinmas, it will be there on Easter as well)

Kui rükkioras enne jüripäeva paigast ära liigub, siis saab enne jaagupipäeva lõigata (If rye crop straightens up before St. George's Day, there may be harvest before St. Jacob's Day) Kui saab sant, siis saab sandi poiss ka (If the beggar gets something, the beggar's boy gets something too)

\section{E2b. Reverse kui (= if or when) -implications (150-550):}

Siis on härjal hända tarvis, kui kiil kallale tuleb (The ox needs his tail when a gadfly attacks)

Ega siis hing hukka ei lähe, kui ihu harida saab (A soul won't perish if the body is cleansed [about corporal punishment])

Ega kade keela, kui helde tahab (A stingy one won't forbid when a generous one wishes)

Küll nõid nõu löüd, ku poig puvva viiäs (Surely a witch will find a way, if her son is taken to gallows)

Abi saab ikka, kui arstitakse (There will be help, if treatment is applied)

Ega kuer siis kiljata, kui kondiga visata (A dog will not squeal when hit by a bone)

Jüripäev kui hobõsõsita pääl ka hallõtki om, sõs saa iks hää suvi (If there is frost at least on horse manure on St. George's Day, there will be a good summer) 


\section{E3. Implications with until-patterns (70-640):}

Koer haugub, kuni külaline tuleb (A dog will bark until a guest arrives)

Seeni sõpra kui sõira (A friend until cheese [hasn't been finished])

Inimene õpib niikaua, kui ta elab (A man learns until he lives) Seni kurg kooles, kui soo sulas (The stork will die before the swamp thaws)

Peni seeni hauk, kui susi karja manu tule (A dog will bark until a wolf comes near the cattle)

Sant tänab seni, kui suu märg on (A beggar's thanks last until his mouth is wet)

E4. Where..., there... -implications and reverse implications with (there)... where... (220-2200):

Kus suitsu, seal sooja (Where there is smoke, there's warmth)

Kus hunti kõneldakse, seal hunt on (A wolf mentioned, a wolf present)

Kus tegijaid, seal nägijaid (Where there are doers, there are witnesses)

Kus suitsu, seal tuld (Where there is smoke, there's fire [= No smoke without fire])

Kus häda kõige suurem, seal abi kõige lähem (Where the need is the greatest, the help is the closest)

Kus õhtu, seal öömaja (Night will give the lodging [literally: Where the evening, there the lodging])

Kus puud raiutakse, seal langevad laastud (Where trees are felled, chips are bound to fall)

Kodu sääl, kus kotid maas (Home is where the package is dumped)

Siga sööb sealt, kus mold ees (A pig eats wherever it finds a trough)

E5. Implications with How many..., so many... (5-10):

Mitu pääd, setu meelt (How many heads, so many minds)

Mitu meest, setu aru (How many men, so many minds)

E6. Implications with Like..., like..., As..., so... etc. and their reverse forms (200-1770):

Kuidas känd, nõnda võsu (Like stump, like twig) 
Kuidas lind, nõnda laul (Like bird, like song)

Kudas küla mulle, nõnda mina külale (The way the village acts towards me, the way I'll react towards the village)

Kuidas lükkad, nõnda läheb (The way you push, the way it goes) Kuidas töö, nõnda palk (As work, as pay)

Kuida vakk, nõnda kaas (As the box, as the lid)

Kuidas metsa hü̈̈ad, nõnda vastu kostab (The way you shout to the forest, the way the forest will resound)

Kuidas külv, nõnda lõikus (Like sowing, like harvest)

Kuidas mets ruttab, nõnda põllumees ka (As the forest hurries on, so does the farmer)

Kuidas ema, nõnda tütar (Like mother, like daughter)

Lind laulab nii, nagu nokk siatud (So the bird will sing, as its beak has grown)

E7. Comparative The ...-er ..., the ...er ... -implications (105820):

Mida armsam laps, seda kibedam vits (The dearer the child, the harder falls the birch)

Mida rohkem koeri koos, seda vesisem lake (The more dogs in the pack, the weaker the lap)

Mida varem, seda parem (The earlier, the better)

Mida kõrgemad lumehanged, seda suuremad viljarõugud (The higher the snowdrifts, the bigger the cornricks)

Mida enam kassi silitad, seda kõrgemale ta saba tõstab (The more you stroke the cat, the higher it raises its tail)

Mida viksim, seda litsim (The more polite, the less reliable)

E8a. Implications with what-antecedent (Mis..., see... and Mida..., seda... -patterns in Estonian) (220-1550):

Mis hundi suus, see hundi kõhus (What is in a wolf's mouth, is in a wolf's stomach)

Mis ajast, see arust (Out of time, out of mind [literally: What is..., is...])

Mida Juku ei õpi, seda Juhan ei tea (What Juku [a boy] doesn't learn, Juhan [as a grown man] won't know)

Mis täna tehtud, see homme hooleta (What is done today, need not be cared about tomorrow)

Mida külvad, seda lõikad (What you sow, you will mow)

Mis meele peal, see keele peal (What is on your mind, is on your tongue) 
Mis koer ei näe, seda koer ei haugu (What the dog doesn't see, it doesn't bark about)

Mis ühe meelest kuld, see teise meelest muld (What is gold for one man, is but dust for another)

E8b. Reverse implications with..., what... (See..., mis..., Ei..., mis..., Kõik..., mis... -formulae in Estonian) (40-230):

Ei aiasiga tea, mis õueseale tarvis on (Never would a fatting pig know what a free-running pig wants)

Härg pillab ühe korraga, mis sä̈̈sk ümber aasta (An ox will drop at a time what a gnat [would drop] round the year)

Kõik on tühi, mis sant laulab (Whatever a beggar sings is vain)

E9a. Implications with He who..., ... (Kes..., see... -formula in Estonian) (460-1840):

Kes teisele auku kaevab, see ise sisse kukub (He who digs a hole for another [to fall], will fall in himself)

Kes kopikat ei korja, see rublat ei saa (He who doesn't save a copeck, won't get a rouble ever)

Kes kannatab, see kaua elab (He who suffers patiently, will live long)

Kes kahju kardab, see õnne ei leia (He who's afraid of risk, won't find his luck)

Kes kõik nõmmed kõntsib, see kõik marjad maitseb (He who walks every moor, knows the taste of every berry)

Kes koera ei sööda, see söödab varast (He who doesn't feed a dog, feeds the thief)

Kes hiljaks jääb, see ilma jääb (He who comes late, gets nothing)

Kes otsib, see leiab (He who seeks will find)

Kes ei täna pisku eest, see ei täna palju eest (He who doesn't thank for a little, will not thank for much either)

Kes naeru kardab, see peeru sureb (He who's afraid of laughter, will die in fart)

Kes palju rä̈̈gib, see palju valetab (He who talks much, tells a lot of lies)

Kes pärast naerab, naerab paremini (He who laughs last, laughs best)

Kes kellaga lehma otsib, see sitase saba saab (He who seeks for a cow with a bell, will get [a cow with] a dirty tail) 
Kes kõik pühad peab, see kõik näljad näeb (He who feasts every holiday, will have to suffer every hunger)

Kes tuult külvab, see tormi lõikab (He who sows wind, will reap storm)

Kes hirmuta kasvab, see auta elab (He who grows without fear, will live without honour)

E9b. Reverse implications with He's..., who... , Such a... that... etc. (40-90):

Ei see siga sigine, kes ei vingu viiessa (Such a pig will not thrive that doesn't squeal when carried off)

Narr on see, kes rohkem lubab, kui ta jõuab (Foolish is the man who promises more than he can do)

Lammas on, kes end niita laseb (It's sheep that has itself shorn)

E9c. Implications with whom-antecedent (Keda..., seda and Keda..., see... in Estonian) and their inverse patterns (15110):

Keda isa ei oppeta, seda õpetab ilm (He who is not taught by father will be taught by the world)

Keda ei näha näämikus, seda ei sihita siidiski (She who is not noticed in plain clothes won't be interesting [literally: aimed] in silk either)

E9d. Implications with whose-antecedent (Kelle..., selle... in Estonian) and their inverse forms (40-610):

Kelle jalg tatsub, selle suu matsub (Whose foot strides, his mouth smacks)

Kelle käed sitaga, selle suu saiaga (Whose hands are in dirt, his mouth is full of white bread)

Kelle laps, selle nimi (Whose the child, his the name [= The seller determines the price])

Kelle leiba ma söön, selle laulu ma laulan (Whose bread I eat, his song I sing)

E9e. Implications with specific He who has... or He who is... -antecedent (Kel..., sel... in Estonian) and their inverse forms (90-610):

Kel janu, sel jalad (He who is thirsty, has the feet)

Kel suur suu, sel lai selg (He who has a big mouth needs a broad back) 
Kel perse sü̈̈däs, küll tuu hindäle sanna kütt (He whose arse itches will heat a sauna for himself)

Kel kärnad, sel küüned (He who has scabs has got nails [to scratch] too)

Kel jõud, sel õigus (He who has power is always right)

E9f. Implications with other case forms of the He who... pattern and inverse structures (15-50):

Kellele palju antud, sellelt ka palju nõutakse (Who has been given a lot, of him a lot is expected)

Seda võib naiseks võtta, kellega vaka soola seltsis oled ää söönud (This woman you can marry, together with whom you have eaten a bushel of salt)

\section{F. Proverb texts with a parallelist supra-level and an indica- tive base}

F1a1. Parallelisms with negative and affirmative forms of simple sentences contrasted (180-2260):

Varas jätab varna seina, tuli ei jäta sedagi (A thief will leave a peg on the wall, fire won't leave even that much)

Küsija suu peale ei lööda, aga võtja käe peale lü̈̈akse (Nobody hits an asking mouth, but a taking hand will be hit)

Suu teeb suure linna, käed ei tee kärbse pesagi (Mouth makes a big town, hands don't build a fly's nest)

Onnetus käib inimesi mööda, mitte kivi ja kändu mööda (Misfortune walks from man to man, not on stones or tree-stumps) Sitke kannab siidi, heldel pole helmigi kaelas (A stingy one walks in silk, an open-handed one has not even a necklace)

Nina otsa näed, aga ea otsa ei näe (The tip of your nose you can see, but you can't see the end of your time)

Ema pistab rinna suhu, aga ei pista meelt pähe (Mother puts the breast in the mouth, but she doesn't put reason in the head) Väsib andja, ei väsi vastuvõtja (A giver may get tired, not the receiver)

F1a2. Parallelisms containing contrastive simple sentences with recurrent elements and/or ellipses (260-1970):

Koera keele otsas rohi, kassi keele otsas tõbi (A dog's tongue carries medicine, a cat's tongue carries disease) 
Sööjal pikk käsi, lööjal lühike (An eater has a long hand, a striking hand is short)

Omad koerad kisuvad, omad koerad lepivad (Own dogs fight, own dogs make peace)

Põua lapsed naeravad, vihma lapsed nutavad (Drought's children laugh, rain's children cry)

Kitsi võtab kirstust, helle võtab persest (A miser takes from a chest, an open-handed one takes from the arse [i.e. leaves nothing in store])

Noorel nugise silmad, vanal varese silmad (A young person has eyes like a marten's, an old person has eyes like a crow's)

Noor koer ärritab, vana salvab (A young dog growls, an old one bites)

Rutaka tüe rumala, hillukse tüe ilusa (The work of a headlong person is unsightly, that of a sedate one is nice)

Herits kitt hinnäst, hüä miis teist (A vain man praises himself, a good man praises another)

Väikesed vargad ripuvad võllas, suured sõidavad tõllas (Small thieves hang on the gallows, big ones ride in chariots)

\section{F1a3. Parallelisms consisting of contrastive simple sen-} tences in which all content words are different (180-1860):

Varane pühib nokka, hiline siputab tiibu (An early [bird] wipes its beak, a late one shakes its wings)

Tegijal tööd, magajal und (A busy man has work to do, a sleeping man has his sleep)

Susi unetas, pini mäletas (The wolf forgets, the dog remembers) Sügisel suured söömad, kevadel keed magusad (In autumn there are big feasts, in spring even chaff tastes sweet)

Ei upsi uus kuub, vaid tantsib täis kõht (A new coat doesn't bounce, but a fed stomach can dance)

Tõsi tõuseb, vale vajub (Truth will rise, untruth will sink)

Vilets vitsul peksetakse, onnis suul oppetakse (A miserable one is birched, a blessed one is taught by words)

Minial on mitu viga, ämmal ei häda kedagi (A daughter-in-law has many faults, there's nothing wrong with a mother-in-law) Rahu kosutab, vaen kaotab (Peace gains, hostility loses) 


\section{F1b1. Parallelisms consisting of synonymous simple sen-}

tences with recurrent elements and/or ellipses (240-1820):

Häda ei anna häbeneda, tühi kõht ei kõrgistada (In need one can't afford feeling ashamed, a hungry stomach can't afford being haughty [= Necessity knows no law])

Ilu ei panda padaje ega kaunist kattelaie (Beauty can't be put in the pot, fair looks can't be put in the kettle)

Kass sööb kaua hoietu, peni pikka peetu (Cats will eat what has been kept too long, dogs will eat what has been saved lengthily) Viha võtab vilja maast, kadedus kalad merest (Anger takes crops from the ground, envy takes fish from the sea)

Kuri võtab kulbist, paha sõna pajast (Spite eats from the scoop, a bad word [eats] from the pot)

Mure teeb mustaks, häda halliks (Heartache makes [the face] dark, worry [brings] gray [to the hair])

Tuli ei taha tuhnakat tegijät, lats laiska hoitjat (Fire doesn't want a clumsy lighter, or a baby a lazy sitter)

Vesine on veliste arm, sõklane on sõsarde arm (Brothers' love is watery, sisters' love is chaffy)

Hull kiidab orja tööd, laisk kiidab lapse tööd (A crazy one would praise a slave's [or: servant's] work, a lazy one would praise a child's work)

Sitast ei saa siidi, kanapasast kalevit (Silk can't be made from shit, or broad cloth from hen's droppings)

\section{F1b2. Parallelisms consisting of synonymous simple sen-} tences in which all content words are different (190-1710):

Merel silmad, metsal kõrvad (The sea has eyes, the forest has ears)

Lehm lüpsab suust, kana muneb nokast (A cow milks from the mouth, a hen lays eggs from the beak)

Ööl üheksa poega, päeval mitu mõtet (A night has nine sons, a day has many ideas)

Jumalal päevi, peremehel leiba (God will give another day, the master will give bread)

Ega naer nahka riku ega tühi jutt tükki võta (Laughter doesn't hurt the skin, nor does a rumour bite a piece off you)

Sädemest tuli, sõnast tüli (Fire [starts] from a spark, a quarrel [begins] from a word) 
Abi aiast, vari võrgust (Even a fence can help, even a net can offer a shelter)

Viletsal visa hing, onnetu kaua elab (A miserable one is tough, a wretched one is hard to die)

Jumal kõrges, kuningas kaugel (God is high above, the King is far away)

Rätsepal ei ole riiet ega kingsepal kinga (A tailor has no clothes, nor a cobbler any shoes)

Tehtud leib sü̈̈akse, kasunud laps leitakse (A baked loaf will be eaten, a grown child will be found)

F1c. Parallelisms consisting of simple sentences in an ambivalent or problematic ideological relation (190-1150):

Meest sõnast, härga sarvest (A man [is held/known] by his word, an ox by his horn)

Sõna pistab, sõna peastab (A word can stab, a word can save)

Vaiv om vanas saia, hä̈̈ om vanan elada (Growing old is hard, but it's good to live an old man's life)

Ega kõrts pole põrguhaud ega kirik pole taevariik (A pub is no hell, nor is church heaven)

Söönud hingab, tõbine oigab (A fed man breathes [i.e. farts], a sick man moans)

Õigus maamehel, õigus meremehel (Right the landsman, right the seaman)

Ori mõist orja opata, varas varast nuhelda (A slave [or: servant] knows how to teach a slave, a thief knows how to punish a thief) $\ddot{U} k s$ tahab ema, tõine tütart (One wants the mother, the other wants the daughter)

Rikkal raha, vaesel latse (A rich man has money, a poor man has children)

F1d. Parallelled simple sentences in a vague temporal or degree relation (260-1100):

Üks patt vargal, üheksa tagaajajal (A thief has sinned once, the pursuer nine times)

Särk on ligi ihu, surm veel ligemal (The shirt is close to the skin, death is closer still)

Üts kord petät pini luuga, tõõnõ kõrd ei petä lihaga (Once you can cheat the dog with a bone, but another time you can't cheat him with meat even) 
Õhtu oli viis paari härgi, homiku ei ole vasikatki (Five pairs of oxen in the evening, not a calf in the morning)

Kördiga ei saa kaugemale kui üle aja hüpata, pudruga saab ommeti teise perese (Gruel won't help you farther than jump over the fence, porridge will take you to the neighbour's house at least)

Rähn on kirev, inimese elu veel kirevam (A woodpecker has many colours, human life has more colours still)

Veri hü̈̈bib harvast, vesi ei hü̈̈bi kunagi (Blood clots seldom, water never does)

Ida vieb kalad meresta, idakakku kattilasta (East wind takes the fish from the sea, east-south wind takes them from the pot) Harvast orja kiidetakse, miniat ei millalgi (A slave [or: servant] is seldom praised, never a daughter-in-law)

Pisike laps vaeotab põlve peal, suur südame peal (A little child presses on the knee, a grown child [presses] on the heart)

F1e. Parallelled simple sentences in a calendary relation (70780):

Laurits laotab lehti, Pärtel pöörab päid (Lawrence spreads the leaves, Bartholomew turns the heads [of cabbages])

Kadri hakkab kusele, aga Andres pistab pulga ette (Catherine begins pissing, but Andrew stops her with a stick)

Parm pask juanipääväni, siäsk miis mihklipääväni (A gadfly is no trouble until St. John's Day, a gnat is active till Michaelmas) Künnipäevaks on virgal maa küntud, aga laisk tõstab veel atra aia pääle (A hard-working man has finished ploughing by Ploughing Day [April 14], when a lazy man is still heaving his plough onto the fence)

F1f. Simple sentences linked in a parallelism by First..., afterwards..., First..., then... etc. (30-70):

Enne töö tehakse, pärast palk maksetakse (Work before, pay after)

Enne mõeldud, pärast tehtud (First thought, then done)

Enne mahub põue, pärast ei mahu enam õue (In the beginning it fits in the bosom, later it won't fit in the yard) 
F1g. Simple sentences linked in a parallelism with $A l$ though..., ... (30-70):

Kahr on küll kuri elläi, siski nahk om iks saksa saani pääl (Although a bear is a wicked animal, his skin can be seen on a gentlefolk's sleigh)

Hanil om küll luine vassar, küll siski ära tund, mis kivi, mis tera (Although a goose has a bony hammer, it will tell a stone from a grain)

F1h. Parallelisms containing a sequence of more than two simple sentences (130-2060):

Aganas on leiva jätku, humalad on ölle jätku, vesi on pitka piima jätku, tuhk on tubaka jätku (Chaff is the extension of bread, hops are the extension of ale, water is the extension of milk, ash is tobacco's extension)

Märt määndab, Kadri kaandab, Simun tei silda soie pääle, Niklus needab, Toomas tore miis sõidab üle (Martin wets, Catherine covers, Simon builds a bridge over bogs, Nicholas rivets, Thomas, a proud man, rides across)

Hommiku hoolekägu, lõuna leinakägu, õhtu õnnekägu ([Heard] in the morning - a cuckoo of charge, in midday - a cuckoo of mourning, in the evening - a cuckoo of luck)

Tõrkuja jägu sü̈̈akse ära, magaja jägu pannakse peaotsi, külaskäija jägu jääta järele (The portion of a reluctant one is eaten up, the portion of a sleeper is put at the bed head, the portion of the one away visiting is saved)

Jaan viskab esimese jahe kivi vette, Jaak teise ja Mihkel kolmanda (John drops the first cold stone in the water, Jacob drops the second and Michael the third)

Põllumees põline rikas, ametmees ajuti rikas, kaupmees korrati rikas (A farmer is eternally rich, an artisan is rich at times, a merchant is sometimes rich)

F2a. Parallelisms consisting of two simple sentences in the form of an equality (metaphor) or comparison (90-460):

Rääkimine hõbe, vaikimine kuld (Talking is silver, silence is gold) Vanatüdruk taevatui, vanapoiss on põrgunui (A spinster is a heavenly dove, an old bachelor is a hellstick) 
Laenaja on sõber, tagasinõudja vaenlane (The one who lends is a friend, the one who reclaims is an enemy)

Võtad naise, nagu regi perän, saad latse, nagu kivi rii pääl (When you marry a woman you feel a sledge behind you, when a child is born, you feel a stone on the sledge)

Vask vaese kuld, tina kehva hõbe (Copper is a poor man's gold, tin is a wretched man's silver)

Vilk vihmavari, tomp tuulevari (A burl protects from rain, a burl protects from wind)

F2b. A parallelist sequence consisting of more than two comparative (simple) sentences (15-60):

Hundile one udu ono, vihim veli ja kaste kaalalõikaja (For a wolf fog is an uncle, rain is a brother, and dew is a throat-cutter)

\section{F3. Parallelisms consisting of two inequalities (2-2):}

Mõtsa varjun parep ku lehe varjun, mehe varjun parep ku mõtsa varjun (A forest shades better than a leaf, a husband shades better than a forest)

\section{F4a. Parallelisms of two elliptical implications (60-230):}

Külmad jõulud, soojad lihavõtted, rohelised jõulud, valged lihavõtted (Frosty Christmas - a warm Easter, a green Christmas - a white Easter)

Virgad vanemad, laisad lapsed, laisad vanemad, virgad lapsed (Hardworking parents - lazy children, lazy parents - hardworking children)

Pisikesed lapsed, pisike mure, suured lapsed, suured mured (Little children - little worry, grown children - big worries)

Suur jalg, suured saapad, suur käsi, suured kindad (A big foot big boots, a big hand - big mittens)

F4b1. Parallelisms consisting of two or more implications with an If..., then... - or When..., then... -formula (80-460):

Kui kägu tuleb vitsa, siis vilja, kui urba, siis ohtu, kui lehte, siis leiba (If a cuckoo alights on a bare tree, there'll be good crops, if on a tree with catkins, there'll be awns, if on a leafy tree, there'll be enough bread) 
Kui luiged madalalt lendavad, siis tuleb madal talv, kui luiged kõrgelt lendavad, siis tuleb sügav talv (If swans fly low, there'll be a shallow winter, if swans fly high, there'll be a deep winter) Kui otsas, siis hooleta, kui vatsas, siis vaevata (When finished, there's no worry, when [the food is] inside, there's no trouble) Kui ligi, siis puskab, kui kaugel, siis ammub (When close, it will butt, when at distance, it will bellow)

F4b2. Parallelisms consisting of two or more inverse implications with (Then)..., when... (10-40):

Mees nägusam, kui piip suus, naine nägusam, kui laps süles (A man looks better when with a pipe, a woman is more beautiful with a child on her knees)

Kullake, kui annad, kurivaim, kui nõuad (A dear friend when giving, a damned nuisance when reclaiming)

F4c.Two parallel implications with ..., until... (1-2):

Nikka ikkä kui ett, nikka põlvõ kui põimu (There is life until there is grain to be cut, there is age until there is crop to be harvested)

F4d. Two parallel implications with Where..., there... (10-40): Kus silm, seal külm, kus sõlm, seal soe (Where there's a loop, it's cold, where there's a burl, it's warm)

Kus haige on, seal on käsi, kus arm on, seal on silm (Where it hurts the hand will go, where there's a love the eye will go)

F4e. Two parallel implications with As..., so..., Which..., such... etc. (10-50):

Kuidas tibu, nõnda tervis, kuidas arst, nõnda abi (Like penny, like health, like doctor, like help)

Nii kui elu, nii om ehte, nii kui rõõm, nii om rõiva (Like life, like ornaments, like joy, like robe)

F4f. Two parallel implications with The ...er, the ...er (1-1): Mida targem rahvas, seda rikkamad, mida rumalamad, seda vaesemad (The cleverer people, the richer, the dumber, the poorer) 
F4g. Two parallel implications with What..., (that) ... etc. (Mis..., see... in Estonian) or their inverse patterns (30230):

Mis kallis, see kaunis, mis odav, see mäda (What is expensive is beautiful, what is cheap is rotten)

Tunnukse ikka, mis vee veeretud, ei tunta saia söödud (It's always clear who [literally: what] has grown on water, it's not clear who has eaten whitebread)

F4h1. Two parallel implications with $\mathrm{He}$ who..., ... or a parallelism consisting of two inverse implications with It's..., who... (45-610):

Kes kooleb, sii kodu lääb, kes elab, sii ette puutub (He who dies will go home, he who lives will be encountered)

Kes teeb, see saab, kel põle teha, sel põle saada (He who works will get something, he who has nothing to do, has nothing to get)

Hea laps, kes hästi tantsib, parem laps, kes paegal seisab (A fair child who dances well, a better child who stands still)

Narr, kes Narvast naise võtab, loll, kes linnast lehma ostab (It's a fool who marries a wife from Narva, it's a dunce who buys a cow in town)

F4h2. Two parallel implications with Kel..., sel... (= He who has... or He who is...) or their inverse forms (15-150):

Kel vägi, sel võimus, kel kukkur, sel kohus (He who has force has power, he who has a [big] purse has justice [on his side])

Ega see pole rikas, kel palju on, vaid see on rikas, kes omaga rahul on (Not he is rich who has much, but he is rich who's contented with what he has)

F4i. A sequence consisting of three or more parallel implications (20-380):

Kured lähvad - kurjad ilmad, haned lähvad-hall taga, luiged lähvad - lumi taga (Cranes going - bad weather, geese going hoarfrost coming, swans going - snow on the ground)

Keda vahites, toda kahites, keda naaretes, toda haaretes, keda otsites, toda trotsites (He who's stared at is envied, he who's laughed at is seized, he whose company is sought is defied) 


\section{G. Imperative sentences}

G1. Sentences that are imperative in content, but indicative or elliptic in form

G1a1. Indicative instructions and standards in the form of simple sentences with should, must, has (got) to etc. (40230):

Tõnisepäevast pidi pool loomatoitu alles olema (On St. Anthony's Day half the fodder had still to be there)

Varust peab koera lööma (A dog should be beaten just in case)

Käsku peab igaüks täitma (An order is for everyone to obey)

G1a2. Indicative prohibitions and warnings with shouldn't, mustn't etc. (30-50):

Ei või kõiki ühe paela peale panna (You can’t string everything on one thread [i.e. equalize])

Narriga ei maksa vaielda (It doesn't pay to argue with a fool) Häätegu ei tohi unustada (A good deed mustn't be forgotten)

G1b1. Orders and recommendations in the form $A$ must be done because... otherwise $B$ will happen etc. (5-10):

Kopikas peab taskus olema, muidu koerad kusevad peale (There should always be a copeck in the pocket, otherwise dogs will piss on you)

Las vares vaagub, küll ta vakka jääb (Let the crow croak, it won't do it forever)

G1b2. Prohibitions and warnings in the form $A$ mustn't be done because... otherwise B will happen etc. (8-10):

Surnu suu pääle ei kästa kohut mõista: patutse oleme keik (One shouldn't condemn a dead man's words - we are all sinful)

Jaanile ei tohi sõnnikuhaisu ninasse lasta, siis ei kasva hää rukis (John shouldn't be let to smell manure, otherwise rye won't grow good grain)

G1c1. Implications with If / When..., (then)..., the consequent member of which is an order or recommendation with peab (= should), or the consequent member is a prohibition or warning with mustn't, shouldn't etc., or their inverse forms (50-120):

Kui tahad targaks saada, siis pead õppima (If you want to become wise, you should study) 
Kui vanad räägivad, peavad lapsed vaid olema (When adults are talking, children should be quiet)

Kui kala ei ole, piab konn mõrda minema (If there's no fish, a frog has to be trapped)

Kui ei või parata, siis peab laskma karata (If you can't help it, let him buck)

Ei massa sis enap värrit kinni panda, ku hobõnõ om ussajast vällä joosnu (It's not worthwhile closing the gate, when the horse has run out of the yard)

Kui sa annad, siis su pahem käsi ei pea teadma, mis parem käsi teeb (When you give, your left hand shouldn't know what your right hand is doing)

Ega siis ei saa änam koera sööta, ku varas juba õues on (You shouldn't feed the dog when the thief is already in the yard)

G1c2. Implications of the form $\mathrm{He}$ who..., ..., the consequent member of which is an order or recommendation with must, has (got) to etc., or an interdiction with shouldn't, mustn't etc. (30-200):

Kes huntide hulgas on, peab nendega uluma (He who is among wolves has got to howl together with them)

Kes ei taha tööd teha, see ei pea ka sööma (He who doesn't want to work, shouldn't eat either)

Kes kuulda ei taha, piab tundma (He who doesn't want to listen, must feel)

Kes algab, peab lõpetama (He who makes a start has got to finish)

G1d. Imperatives with should, mustn't etc., that contain some parallel (contrasted or synonymous) components (35-90):

Tüdrukust ja hernest ei või kunagi ilma pudumata mööda minna (Neither a girl nor a pea plant can ever be passed by without laying hands on them)

Vanna võit naarda, a hädälist naargu-ui, vanast lätt egäüts (You may laugh at an old person, but not at a sick one, everyone will get old once)

Silmaga võib küll vaadata, käega ei või mitte keiki katsuda (You can use your eyes, but you cannot use your hands on every thing) Elu peab elama, ussi peab tapma (Life has to be lived, a snake has to be killed) 
Sõnal peab sõlm ja jutul jakk olema (A word should have a knot on it and a story should have a continuation)

\section{G1e1. Various non-parallelist elliptic structures that are indicative in form, but imperative in contents (10-180):}

Mees mehe vasta (Man for man)

Kirik keset küla (A church [shold be built] in the centre of a village [about compromises])

Vorst vorsti vastu (A sausage for a sausage)

Magajalle piaalust ([Something to be put] under the head of the sleeper)

\section{G1e2. Two parallel ellipses, that by content are orders or} rules $(60-450)$ :

Rügä tuhka, tõug mutta (Winter rye [should be sown] to ashes [i.e. dry soil], spring cereal to mud)

Noorelkuul nurme, vanalkuul varju (By new moon [sheep should be shorn] in the open, by old moon in the shade)

Kanadega magama, sigadega üles (To bed with hens, up with hogs)

Silm silma vastu, hammas hamba vastu (An eye for an eye, a tooth for a tooth)

Haigele arsti, tervele vorsti (A doctor for the sick man, some sausage for the healthy one)

\section{G2. 3rd person imperatives}

G2a. Hyperbolic a.o. texts in the form Let there be A or B... or Even if..., still... or ..., if only... (30-170):

Olgu isa sikk või ema kits, kui aga ise mees olen (Let the father be a billy-goat or the mother a nanny-goat, the main thing is that I'm a real man)

Olgu sant või vigane, pääasi et on isane (Let him be defective or disabled, the main thing is he's a male)

Ega pini ilma ei haugu, olgu susi ehk tõrvaskand (A dog won't bark in vain, be it at a wolf or a pitch stump)

Olgu aed nii suur kui ta on, mulk ikka üks (No matter how large the pen may be, a gate is a gate)

Olgu poiss kolmest kohast õlesidemega kinni, ikka saab naise (Even if a boy is bandaged with straw in three places, he will have a wife) 
G2b. Optative sentences beginning with God forbid, God grant etc. (20-80):

Jumal hoia mind sõbra eest, vaenlase eest ma hoian ennast ise (God protect me from a friend, from the enemy I'll protect me myself)

Jumal lasku sõaväge ikka kuulda, ei elades näha (God let us hear the army, never see it)

Jumal hoidku häda iist, risti ja viletsust isegi küll (God save us from trouble, there's misery and woe enough as it is)

Jumal hoidku selle eest, ku orjast otsaline saab (God forbid a slave [or: servant] from becoming a master)

Jumal andku ikka anda, aga mitte otsi (God grant us the role of a giver, not of the one who begs)

G2c. Simple sentences with a 3rd person $g u$-, $k u$-imperative (30-70):

Kingsepp jäägu oma liistude juurde (A cobbler should stick to his lasts)

Igaüks kratsigu ise oma kärnad (Every man should scratch his own scabs)

Õigus olgu igaühele (Justice should be for everyone)

Igaüks pühkigu oma ukseesist (Everyone should sweep before his own door)

\section{G2d. $g \boldsymbol{u}$-, $\boldsymbol{k u}$-imperatives in the form of an inequality (2-2):}

Tagumised väravad olgu ikka vähemad kui esimesed (The back gates should always be narrower than the front ones [about sparing])

G2e1. Implications with If/When..., let... (someone) should (not)... etc. or an ellipsis (gu-, $k u$-imperatives in Estonian) (20-190):

Kui kaks kõnelevad, pistku kolmas nõna vöö vahele (When two are talking, the third should stick his nose in the belt [i.e. keep aside])

Latsele lauldas, mõrsja mõistku (A child is sung to, a bride should understand)

Kui on pühad, siis olgu pühad (Once a feast, let's feast)

Kui on läinud trumm, siis mingu ka pulgad (Once the drum is gone, let the sticks go as well) 
G2e2. Implications with He who... should (not)... etc. or with an ellipsis (gu-, $\boldsymbol{k u}$-imperatives in Estonian) (15-50):

Kes on pandud orjama, see orjaku hea meelega (He who has got to slave, ought to slave with delight)

Kes koore päält sööb, see söögu ka sisu (He who eats the crust, should eat the crumb too)

Kes parem mõistab, see parem tehku (He who knows better, should do better)

G2e3. Other implications with ... should (not) do... etc. in the consequent member ( $g u$-, $k u$-imperatives in Estonian) (350):

Mida parem on hobune, seda parem olgu piits (The better the horse, the better the whip should be)

G2f1. Texts with one verb on $-g u,-k u$ linking at least two (contrasting or synonymous) components (15-30):

Silmad olgu ikka ees ja taga (One should always have eyes both in front and at the back)

Tütärlats pidägu suu, käe ja perse (A girl should hold her mouth, hands and arse)

Möldri matt ja kõrtsi mõõt olgu maksetud (A millers toll and a tavern measure should be paid)

G2f2. Fully parallelist texts with imperatives on -gu, -ku (2060):

Muи puu muhaku, lepa leht lehaku, tütarlats olke vaik (Other trees may sough, an alder leaf may murmur, a girl should be quiet)

Soe olgu söönü, lamba olgu alale (Wolves should be fed, but the sheep should survive)

Hull võib olla ôlle tegija, aga tark olgu linnase tegija (Ale can be made by a crazy man, but malt should be made by a clever man)

\section{G3. You-imperatives}

G3a1. Orders and recommendations in the form of an imperative simple sentence $(30-250)$ :

Sea suu sekki mööda (Adjust your mouth by the wallet [literally: sack]) 
Pea pool suud kinni (Hold half of your mouth shut)

Naist kiida aasta pärast (Praise your wife in a year's time [earlier it is not sure if she deserves it])

Anna aega atra seada (Allow [them/us] some time to get the plough ready)

Jäta viimane hoop löömata (Save the last blow)

G3a2. Prohibitions and warnings in the form of an imperative simple sentence (100-660):

Ära hõiska enne õhtut (Don't jubilate before the day is done)

Tänasida toimetusi ära viska homse varna (Don't hang today's work on the tomorrow's peg)

Ära kiida ilma enne õhtut (Don't praise weather before evening) Ära ôhtast aset kiida (Don't praise your bed in the evening)

Ära põlga esimest õnne ial ära (Don't you ever disdain your first happy chance)

Ära pista pead tulle (Don't put your head in the fire)

Ära maksa kurja kurjaga (Don't pay an evil deed back with an evil deed)

G3b. Preferences a.o. inequalities containing an imperative verb form (15-40):

Parem kae sittuja silmi kui puuraiuja silmi (You better look in the eyes of a shitting man than in the eyes of a woodcutter [it is dangerous to stand near the woodcutter because you can be hit by woodchips])

Parem võta sammu pealt kopik kui versta pealt rubla (You better take a copeck for a pace than a rouble for a verst)

Paremb korja munakoorõ sisse kui lehma nissa (You better collect in an eggshell than in a cow's teat)

G3c1. Orders and recommendations in the form $D o A$, because B... otherwise $B$ will happen etc., or prohibitions and warnings in the form Don't $d o A$, because $B$... otherwise $B$ will happen etc. (55-320):

Võta naene naabritalust, teda tunned käsist-jalust (Marry a girl from the neighbouring hut, for her you know by hand and foot) Hoidke omad mokad lukku, muidu lennab kärbes kurku (Keep your lips locked, or a fly will get down your throat) 
Õle oma sõnale peremees, muidu saab sõna sulle peremeheks (Be a master of your word, otherwise your word will be your master)

Ära usu ilma, ilm ajab puru silma (Don't believe the world, the world will throw dust in your eyes)

Ära sitta puudu, sitt hakkab haisema (Don't touch shit, shit will stink)

Ära usu hundi juttu, hundil on need hullud jutud (Don't believe a wolf's story, a wolf's stories are wicked)

Ära narri koera, koer salvab (Don't tease a dog, a dog will bite)

G3c2. Orders and recommendations in the form $D o A$, then you'll get / preserve $B$, or prohibitions and warnings of the form Don't do A, then you'll avoid B (60-260):

Hoia ise, siis hoiab ka Jumal (Take care of yourself, then God will take care of you too)

Tee tööd higiga, siis sööd leiba himuga (You work with sweat [on your back], then you'll eat with appetite)

Pea suu kinni, seisab selg terve (Keep your mouth shut, then your back will remain intact)

Korja õigel ajal, siis on sul häda ajal (Save in the right time, then you'll have something in hard times)

Ära tee teisele head, siis ei sünni sulle kurja (Don't do favours, then nothing bad will happen to you)

Ära ennast liiga kiida, siis sind keegi ka ei laida (Don't praise yourself too much, then nobody will find fault with you either)

G3d1. Implications of the form If / When..., then... or of the inverse form, the consequent member of which is an order or recommendation in the imperative form, also implications with If / When..., don't..., Don't... before... or the inverse form, the consequent member of which is a prohibition or warning in the imperative form (170-1150):

Pista põrsas kotti, kui pakutakse (Put the piglet in the bag when offered)

Tao rauda, kui raud kuum on (Work the iron when it's hot)

Paranda, kui paras aeg on (Mend when the time is right)

Kui midagi teed, tee hästi (Whenever you do anything, do it well) Kui sõna ei aita, siis lase käsi käia (If a word isn't enough, use the hand) 
Ära enne vana kaevu täis aja, kui uus valmis ei ole (Don't fill an old well before the new one is ready)

Ära sööda siis koera, kui hunt karjas on (Don't feed the dog when a wolf is at the cattle)

Ära mü̈̈ enne karu nahka ku karu käes (Don't sell a bear's skin before the bear is caught)

Kui katel keeb, ära sa enam tuld alla ajag (When the kettle is boiling, don't keep feeding the fire)

G3d2. Implications of other forms, the consequent member of which is a prohibition or order in the imperative form (15-50):

Ära lükka homse peale, mis sa täna võid teha (Don't put off till tomorrow what you can do today)

Ära sinna tuld tee, kus keige suurem vesi (Don't make fire where there's most water)

Pane aga pauna, mis pakutakse (Put in the pouch what is offered)

G3e1. Sentences with parallel (contrasting, synonymous etc.) components containing a verb in the imperative (20-90): Kolmõ asja sisse ära usu kunagi: tühja huunõt, mõtsa ja makajat (Never trust these three things: an empty building, the forest and a sleeping person)

Lapsele anna hirmu ja armu (Give a child birch as well as love) Ära usu suure saksa suud ja pisukese lapse perset (Don't trust a big nob's mouth or a little child's bottom)

Avida menejat mõrsjat ja asujat majja (Help a leaving bride and a newcomer in the house)

G3e2. Parallelisms consisting of two simple sentences conveying an order or recommendation / a prohibition or warning in the imperative form (130-920):

Rikkast perest osta hobune, vaesest vallast võta naene (Buy a horse from a wealthy farm, marry a wife from a poor parish) Tee tööd töö ajal, aja juttu jutu ajal (Work at working time, talk at talking time)

Halli pead austa, kulupead kummarda (Honour a grey head, bow to a bald head)

Ela ise ja lase teisi ka elada (Live and let others live) 
Üheksa korda mõõda, üks kord lõika (Measure nine times, cut once)

Anna antust, murra murtust (Give of what has been given to you, break from what has been broken for you)

Võta pits ja pea aru (Take a drop but be moderate)

Tee tööd ja palu Jumalat (Work and pray)

Võõrast ära võta, oma ära jäta (Don't take what's someone else's, don't give up what's your's)

Kanget ähvärdamist ärä pelga, suurt lubamist ärä looda (Don't be scared by loud threats, don't hope much of big promises)

Ära usu uisu juttu ega pea poisi pettu (Don't believe a snake's word, don't trust a boy's tricks)

\section{G3e3. Parallelisms consisting of two contrasting simple sen- tences, one of which communicates an order, the other a prohibition (80-720):}

Narri meest, ära narri mehe mütsi (Gibe a man, not a man's cap)

Võta vana sõna, aga ära söö vana osa (Take an old person's word, don't eat an old person's portion)

Ära kiida iseennast, lase teised kiita (Don't praise yourself, let others do it)

Rä̈̈gi meest, aga ära nimeta meest (Speak of a man, but don't use his name [i.e. speak allusively])

Ära kiitle kinda sees, tule seisa meeste ees (Don't you boast [with your hand] in a glove, come out and stand up before men)

\section{G3e4. Parallel sequences consisting of three or more impera-} tive simple sentences (20-100):

Nä̈ palju, kuule palju, ära palju pajada (See a lot, hear a lot, don't say a lot)

Tii esi, tõhuta tõist, astu esi, aja muid (Work yourself, encourage others, go your way, drive others on)

Unusta uni, mäleta mälu, pea noor mees meeles (Forget sleep, remember what happened, keep the young man on your mind) Ära pilka vigast, ära põlga vaest ega narri nõtra (Don't mock at a cripple, don't scorn a poor man or fool a feeble one) 
G3e5. Parallel imperative components of a compound sentence with First..., then... etc. (30-280):

Enne mõtle, siis ütle (First think, then say)

Pühi enne oma ukseedine puhtaks, siis mine teistel pühkima (First sweep in front of your own door, then go sweeping before the others')

Enne mune, siis kaaguta (First lay an egg, then cackle)

Tee enne, kiida pärast (First do, then boast)

G3f1. Texts of the form Do / Don't do A, because... or otherwise $B$ will happen, with a parallelist initial component in the imperative form (25-150):

Tee tööd ja näe vaeva, siis saad taeva (Toil and moil, then you'll get to heaven)

Vaata ette, vaata taha, muidu jääd sa ajast maha (Look out, look back, otherwise you'll fall behind the times)

Pea ennast kolmest kinni: käed suu ja perse, siis saad ilmast hästi läbi (Keep yourself bound in three places - hands, mouth and arse, then you'll get on well in the world)

G3f2. Patterns consisting of two or more parallel implications with If / When A, then do B or If / When A, don't do B and an imperative verb (50-400):

Kui mees on hea, pista tal üks silm ära, kui paha, kaks silma (If your husband is good, stab one eye out of him, if bad, stab two eyes [about sharing secrets, making expenses etc.])

Läheb jahimees metsa, pane pada kummuli, läheb kalamees kalale, pane pada tulele (When a hunter goes to the forest, turn the kettle upside down, when a fisher goes fishing, put the kettle on)

Kui kuuled, ära pane kuulvas, kui näed, ära pane nägevas (If you hear, don't show you've heard, if you see, don't show you've seen)

Oled vaene, siis ole vaiki, oled perätü, sis pia suu (If you're poor, keep quiet, if you are necessitous, just hold your mouth) 
G3f3. Various complex sentences containing imperatives (40150):

Mis sa tahad, et teised peavad sinule tegema, sedasama tee sina ka teistele (What you want to be done unto you, you do unto others too)

Varasta, aga mitte nõnda, et üles tuleb (Steal, but don't be caught) Kott olgu ikka enesest, saagu põrss kust saa (Your bag should always be ready, whence ever the piglet)

\section{G4. Rhetorical orders}

G4a. Rhetorical orders in the form of simple sentences (20130):

Paku pagarilapsele saia (Just go and offer whitebread to a baker's child)

Võta vähilt villu (Just go and take fleece from a crayfish)

Mine nü̈̈d vasikaga võidu jooksma (Just go racing a calf)

Mine hundi suust tagasi võtma (Just go taking anything back from a wolf's mouth)

G4b1. Rhetorical orders with a consequent on see if, ask if etc. (5-6):

Anna aitäh kassi ehk koera kätte, katsu, kas elab sellega (Just you give 'thank you' to a cat or dog, see if it will live on it)

Küsi kassilt, kas tal küisi on (Just ask a cat whether it has claws)

G4b2. Rhetorical orders followed by a member with and yet etc. (implying uselessness) (20-50):

Sööda hunti, hunt vaatab ikka metsa poole (Just feed a wolf the wolf will keep his eyes on the forest)

Poe küll raudpähkle sisse, aga Jumal nääb sind sinnagi (Just hide in an iron nutshell, God will see you even there)

Viska koerale kont suhu, hakkab ommeti pärast jälle urisema (You throw a bone in a dog's mouth, yet it will growl again later)

\section{G4b3. Rhetorical orders followed by a forecast of bad con-} sequences (50-1350):

Lase sant sauna, sant tahab lavale ka (Just you let a beggar in the sauna - the beggar will want to get to the platform as well) 
Narri põldu üks kord, põld narrib sind üheksa korda (You deceive the field once, the field will deceive you nine times)

Anna perse külasse, siis situ ise läbi küljeluie (Lend your arse to the village, then you'll have to shit through the ribs)

Anna pill hullu kätte, hull ajab pilli lõhki (Just you give an instrument to a madman - the madman will blow the thing asunder)

G4c. A rhetorical order as the consequent member of an If / When..., then... -implication (10-20):

Kui nälg kääs, siis pane hambad varna (When hunger's there, just hang your teeth on a peg)

Kuera ei ole - haugu ise (No dog - do the barking yourself)

Mine siis viil laeva ehitama, kui uputus käes (Just go and start building a ship when there's flood)

G4d1. Parallelist equalities with an or-copula, consisting of two rhetorical questions (15-250):

Mine vihata sauna ehk rahata linna (Just you go to the sauna without a bath-whisk or to town without money on you)

Tee tigedale head ehk kaitse kõhna karja (Just you do a good turn to an evil man, or guard the cattle of a wicked one)

Löö koera ehk silita koera (Beat a dog or stroke a dog [it's the same thing])

Mine surnut arstima või tarka õpetama (Just you go doctoring a dead man or teaching a clever man)

G4d2. Two parallelled (contrasting or synonymous) rhetorical orders, followed by a component with and yet etc., implying uselessness (15-200):

Mine suurt saama, jämedad jägama, viimaks peenike pihus (Just you go after something big, after a bulky share - in the end you'll find yourself in trouble [literally: holding a thin end])

Saada siga Saksamaale, pese siga seebiga, siga tuleb koju, siga jääb seaks (Just you send a pig to Germany, wash a pig with soap - the pig will come home, the pig will remain a pig)

Keedä sitta, küdsätä sitta, sitt jääb ikki sitas (Cook shit, bake shit - shit will remain shit) 


\section{H. Rhetorical questions}

\section{H1. Rhetorical questions on who (100-900):}

Kes koera saba kergitab, kui ta ise (Who else will raise a dog's tail but itself?)

Kes virga vilja ära sööb, kui laisku maa peal ei ole (Who would eat the busy man's crops, if there were no lazy people on the earth?)

Kes ilma suu kinni paneb (Who could close the world's mouth?) Kes kitsi karjaelajaks arvab (Who would count goats among cattle?)

Kes kassile kala annab (Who would feed a cat on fish?)

Kes võib santi sundida, kui sant ei taha kõndida (Who can make a cripple walk if the cripple doesn't want to?)

Kes ähnä oonde tääd, kui ei tikuta (Who would find a woodpecker's hollow if it didn't give a sound?)

\section{H2. Texts beginning with a rhetorical what-question (110-} 560):

Mis sest kasu, kui lehm palju piima annab, aga jalaga ümber lööb (What's the use of a cow milking well, but knocking the pail over?)

Mis lind see on, kes oma sulgi ei jõua kanda (What bird can't carry its own feathers)

Mis seda sitta rattile sä̈̈da, mis rattil ei saisa (What's the use of filling the cart with such manure that doesn't keep on the cart?) Mes see ute huikamine, kui see pässi pääd ei pööra (What's the use of a ewe's call, if the ram doesn't turn it's head?)

\section{H3. Rhetorical questions on where, where to or where from} (30-190):

Kuhu sitt rattast jääb (Where does manure go from a cart? [Sure something will stick])

Kus Must muu jätt (Where will Must [a black dog] leave its ways?)

Kus muldine lumi on (Where's last year's snow?)

Kust rikas raha saab (Where does a rich man get his money from?) 


\section{H4. Rhetorical questions on when (20-40):}

Kunas sepal väist om ehk kingsepal korraline saabas (Will a blacksmith ever have a knife or a cobbler wear good boots?) Millal härjäl enne vasik oo old (When has a bull ever had a calf before?)

Millal must koer valgeks läheb (When will a black dog turn white?)

H5. Texts beginning with rhetorical questions on how long and how far (20-150):

Kui kaua koera kaelas vorst seisab (How long will a sausage hang on a dog's neck?)

Kaua vasikas palvetega elab (How long will a calf live on prayers?)

Kauaks kala kassi ees (How long will fish keep before a cat?)

Kaua naaskel kottis seisab (How long will a bodkin keep in a bag?)

Kaugele lind ühe tiivaga linnub (How far will a bird fly on one wing?)

H6. Rhetorical questions on why (7-60):

Mispärast siis sepp käed tulle pistab, kui pihid ees on (Why should a blacksmith stick his hands in fire, when the tongs are there?)

Mispärast kuer leiba süeb, kui ta ei haugu (Why does the dog eat bread if it doesn't bark?)

H7. Texts beginning with a rhetorical general question (kas in Estonian) (10-10):

Kas jõutumal vara on (Has a poor man any property?)

Kas kodul ratta all om või (Does a home have wheels?)

Kas keedet pada söömäldä jääse (Will cooked food ever remain uneaten?)

H8. Rhetorical texts beginning with how much, how many (8-40):

Palju patuselle tarvis on, pista sõrmega silma - süda täis (How much can a sinful man take - just poke a finger in his eye and he's raving mad) 
Metuks mullale vaja (How much does an old person need?)

H9. Texts beginning with a rhetorical question on eks (2-6):

Eks naer tule ikka nuttes koju (Well, won't laughter come home weeping?)

H10. Texts beginning with a rhetorical question on või (1070):

Või taud tühjast toast midagi võtab (Do you think the plague would take something from an empty room?)

Või siga tääb, mis raba on (Do you think a pig would know what draff is?)

Või Kirep killan seisäp (Do you think Kirep [a spotted dog] would stay in a pack?)

H11. Elliptic patterns that can be interpreted as rhetorical questions (4-5):

Hädä hülgel vees (What's wrong with a seal in water?)

Vigaks suure kivi taga hõisata (Do you think it's hard to cheer behind a big boulder?)

H12. Rhetorical questions in sentences containing various parallel components $(\mathbf{6 0 - 5 1 0})$ :

Kes vaest varrule kutsub või puujalga pulma (Who would ask a poor man to the christening feast or a timbertoes to wedding?) Kus koeral kodu või hundil öömaja (Where's there a dog's house or a wolf's lodging?)

Kunas koke kulp isune vai taaripulk janune (When is a cock's ladle hungry or the stopper of a beer keg thirsty?)

Kes kassi pärast läheb randa ehk kitse pärast lakka (Who'd go to the seashore for a cat or to the loft for a goat?)

Kohes kirep killast vai must peni hattsajast jää (Do you think Spot would stray from a pack or a black dog would miss a rutting season?)

Kes kodu musta vai teo laiska kaes (Who would notice dirt at home or lazyness at compulsory service?)

Kauas lühike laul laulet või vaese heng võet (Do you think a short song or a poor man's soul would last long?) 


\section{Exceptional forms}

\section{I1. If-repartees (oleks in Estonian) in the form of an impli- cation, in the past form etc. (60-240):}

Oleks on paha poiss ('If' is a bad boy)

Oleks seal kü̈̈ned, ta läheks puu otsa (If a pig had nails, it would climb a tree)

Oleks tädil till, oleks onu (If auntie had a wee-wee, she would be uncle)

Oleks see koer mitte sitale läinud, ta oleks jänese kätte saanud (If the dog hadn't gone to shit, it would sure have caught the hare)

Oleks uppus ä̈̈ Jamburi jõkke ('If' got drowned in the Jambur river)

Oleks ja peaks on vennad ('If' and 'should' are brothers)

I2. Texts in the form Not all A are B etc. perceivable as partial negation (20-160):

[ See also D. Mesher's opinion:

http://www.sjsu.edu/depts/itl/graphics/claims/univer.html ]

Kõik ei ole kuld, mis hiilgab (All that glitters is not gold)

Iga punane mari ei ole mitte maasikas (Every red berry is not a strawberry)

Kõik ei ole hõpe, mis läügüs (Not all is silver that shimmers)

Iga kana, kes kaagutab, ei mune (Every cackling hen doesn't lay eggs)

Ei ole kõik mesi, mis tilgub, ega kõik tuli, mis välgub (Not all is honey that trickles, nor is all fire that flickers)

\section{I3. Didactic monologues (100-340):}

Vaskuss oli pidan ütlema, et kui tal silmad oleks, siis ta paneks ühe ööga üheksa pere uksed kinni (A blindworm is told to have said that if it had eyes to see, it would close the doors of nine farms [killing the people] in one night)

Kala ütelnud: "Jumal hoidku mind üleliia vaese või rikka kätte sattumast: rikas nülib naha seljast, vaene silmad peast” (A fish is told to have said: "God forbid me be caught by a too poor or a too rich man: a rich man would flay me, a poor man would eat out my eyes") 
Paastukuu ütelnud küünlakuule: "Oleks mina sinust olema, ma võtaks kõik põnnpead põrandale, naese käed leevaastja ja koera kü̈̈sed künnisele, aga ma ei saa, mu teine silm jookseb vett" (March is told to have said to February: "If I were you I would freeze all nippers on the floor [inside], a woman's hands in the dough and a dog's claws on the threshold, but I can't - one of my eyes is dripping")

Täi ütelnud: "Kurika all kuulan, pajas paisun, aga saanalein on hingevõtja" (A louse is told to have said: "Under the beetle I listen, in the kettle I bloat, but sauna steam is lethal to me")

Kaer ütelnud peremehele külviaegas: "Oleks sa mind sinna mua peale külvaks, kus odra külvad, ma paneks sulle kalevipüksid kohe jalga" (Oats are told to have said to the farmer at sowing time: "If you sowed me where you sow barley, I would dress you in broadcloth trousers at once")

As the reader has surely noticed, such traveling from one syntactic-modal cliché to another as well as to and fro between the syntactic-modal and other structural levels of proverbs can take us to extremely complicated and intriguing relations and regularities, which certainly deserve a separate analysis to come.

Translated by Sirje Ainsaar

\section{References}

Eesti vanasõnad. Ed. by A. Krikmann \& I. Sarv. Comp. by A. Hussar, A. Krikmann, E. Normann, V. Pino, I. Sarv, R. Saukas. Vol. I-V:2. Tallinn, 1980-1988.

Vanasõnaraamat. Comp. by A.Hussar, A.Krikmann, I.Sarv. Tallinn, 1984.

[ See also E-versions of Vanasõnaraamat in Estonian

http://haldjas.folklore.ee/ kriku/VSR/FRAMEST.HTM

and German

http://haldjas.folklore.ee/ kriku/VSR/FRAMEGER.HTM ]

Krikmann, A. 1984. 1001 Frage zur logischen Struktur der Sprichwörter. Semiotische Studien zum Sprichwort. Simple Forms Reconsidered I. Special Issue of Kodikas/Code - Ars Semeiotica. An International Journal of Semiotics. Vol. 7, No. 3/4, pp. 387-408. 
Krikmann, A. 1987. 1001 küsimust vanasõnade loogilise struktuuri kohta. Dialoogi mudelid ja eesti keel. TRÜ toimetised, nr 795. Tartu, pp. 120-150.

Lakoff, G. 1987. Women, Fire, and Dangerous Things. Chicago, 1987. 